\title{
Rendemen dan Fisiko-Kimia Keripik Nangka (Arthocarpus sp) Berdasar Masa Masak Optimal Buah
}

\author{
Ribut Suryanto \\ Balai Pendidikan dan Pelatihan Pertanian, Propinsi Nusa Tenggara Barat, Mataram, Indonesia
}

\begin{abstract}
Abstrak
Masa panen buah nangka yang bersamaan seringkali menimbulkan masalah dalam penanganan pasca panen dan penentuan saat pengolahannya. Sesaat setelah dipanen buah nangka cepat mengalami penurunan mutu karena respirasi. Buah nangka dapat diolah menjadi keripik-nangka. Tujuan penelitian ini adalah untuk mengetahui pengaruh perbedaan masa penggunaan bahan baku dari masak optimal menjadi keripik buah nangka terhadap rendemen dan fisikokimia keripik nangkanya. Buah nangka jenis salak masak optimal 0 hari dan masak 1, 2 dan 3 hari digunakan dan diolah menjadi keripik dengan penggoreng vakum. Parameter yang diamati pada keripik nangka adalah rendemen, warna, pengkerutan, dan tingkat kerapuhan. Warna keripik ditentukan berdasar nilai $\delta E^{*}$, pengkerutan diukur berdasar rasio kehilangan kandungan air bahan, dan tingkat kerapuhan dengan texture analyzer. Data yang didapat dianalisis keragaman satu arah dan selang kepercayaan yang digunakan 5\%. Hasil menunjukkan bahwa rendemen, warna, pengkerutan, dan kerapuhan keripik nangka yang didapat hanya diperoleh dari bahan baku buah nangka masak 1 hari dari masak optimal yang tidak berbeda nyata dengan bahan baku nangka masak optimal 0 hari. Kesimpulan bahwa masa penggunaan buah nangka masak 1 hari dari masak optimal untuk diolah menjadi keripik nangka memiliki rendemen, warna, pengkerutan dan kerapuhan yang serupa dengan masak optimal 0 hari.
\end{abstract}

Kata kunci: Fisikokimia, Keripik Nangka, Masak Optimal, Penggoreng Vakum, Rendemen

\begin{abstract}
The same time of Jackfruit harvest time sometimes causes the problem on the post-harvest processing and determination of its processing time. At the harvesting moment, its fruit undergoes the decreasing of quality caused by respiration. This fruit is a fruit that can be processed and made to crispy chips. Objective of this study was to know effects of difference of optimal maturation time of jackfruit fruit on yield and physicochemical of jackfruit crispy chips. Jackfruit of the Salak- cultivar with the optimal maturation time on 0 day and 1,2 , and 3 days of maturation was processed to crispy chips by vacuum frying. The color and brittleness level of crispy chips were determined based on $\delta \mathrm{E}^{*}$ and by texture analyzer. Data were analyzed in one way variance and the significance level was $5 \%$. The result showed that yield, color, shrinkage, and brittleness of jackfruit crispy chips that obtained only from the raw material of jackfruit with 1 day from the optimal maturation time was not significant with optimal maturation. The usage time of jackfruit on 1 day from optimal maturation time to be processed to jackfruit crispy chips have equally with the optimal maturation of jackfruit on the yield, color, and hardness level of jackfruit crispy chips.
\end{abstract}

Keywords: Jackfruit Chips, Physicochemical, The Optimal Of Maturation Time, Vacuum Frying, Yield

\section{PENDAHULUAN}

Nangka adalah tanaman buah yang diyakini berasal dari barat daya India. Jenis-jenis liarnya masih didapati tumbuh tersebar di hutan hujan di sana. Kini nangka telah menyebar luas di berbagai daerah tropik, terutama di Asia Tenggara.Pohon nangka yang berasal dari biji, mulai berbunga pada umur 2-8 tahun, sementara itu yang berasal dari klon mulai berbunga di umur 2-4 tahun. Di tempat yang cocok, nangka

Alamat Korespondensi Penulis: Ribut Suryanto

Email : ribut@yahoo.com

Alamat : Balai Pendidikan dan Pelatihan Pertanian, Propinsi Nusa Tenggara Barat, Mataram, Indonesia dapat berbuah sepanjang tahun,akan tetapi di Thailand dan India, panen raya terjadi antara Januari - Agustus, sementara di Malaysia antara April - Agustus atau September - Desember. Di Indonesia, buah nangka tergolong buah yang dapat diperoleh sepanjang tahun [1].

Varian nangka banyak jenisnya, dari segi sifat buahnya, buah nangka dapat dikelompokkan menjadi dua yakni: (1) Nangka bubur (Indonesia dan Malaysia), yang disebut pula sebagai khanun lamoud (Thailand), vela (Srilangka) atau koozha chakka (India selatan) berciri daging buah tipis,berserat, lunak dan membubur, rasanya asam manis, dan berbau harum tajam (2). Nangka salak (Ind.), nangka belulang (Mal.), khanun nang (Thai), varaka (Srilangka), atau 
koozha pusham (India selatan) dengan ciri daging buah tebal, keras, mengeripik, rasa manis agak pahit, dan tak begitu harum. Perbedaan varian tanaman buah nangka, juga akan memberikan mutu buah yang dihasilkan $[1,3 ; 4]$.

Buah nangka merupakan salah satu bahan pangan yang mudah mengalami kemunduran mutu bahkan pembusukan. Hal ini dapat diakibatkan oleh buruknya penanganan pasca panen dan adanya proses respirasi [2, 5]. Tingkat kematangan saat panen sangat menentukan kualitas produk olahan. Mutu buah setelah dipanen tidak dapat diperbaiki atau ditingkatkan, tetapi dapat dipertahankan. Mutu buah yang baik akan diperoleh bila pemanenan dilakukan pada tingkat ketuaan yang tepat, buah nangka umumnya dapat dipanen pada umur 130-140 hari dari bunga kembang $[1 ; 6]$.

Pengeringan merupakan salah satu teknologi olahan bahan pangan yang salah satu tujuannya untuk penanganan pasca panen dan produksi produk yang berdaya simpan yang panjang. Keripik adalah produk olahan yang berciri memiliki kadar air yang rendah diakibatkan produk mengalami banyak kehilangan air karena proses pengeringan. Penggorengan vakum merupakan salah satu teknologi pengeringan yang digunakan untuk mendapatkan produk kering yang memiliki mutu lebih baik dari produk hasil pengeringan secara konvensional $[7,8]$.

Penelitian ini bertujuan untuk mengetahui perbedaan masa penanganan dari tingkat kematangan buah nangka optimal terhadap rendemen, warna, pengkerutan, dan kerapuhan keripik buah nangka.

\section{BAHAN DAN METODE}

Buah nangka jenis salak yang masak optimal diperoleh dari tanaman nangka yang berada di pulau Lombok. Penggoreng vakum berkapasitas 3 kg dipergunakan sebagai mesin penggoreng dan pembuat keripik buah nangka. Penelitian ini dirancang dengan Rancangan Acak Lengkap (RAL) dengan ragam bebasnya adalah buah nangka dengan masak optimal (0 hari) dan masak 1, 2, dan 3 hari.

Buah nangka masak optimal (0 hari), nangka matang (1 hari, 2 hari, dan 3 hari) yang bersih dari kulit dan biji, dipotong-potong sesuai ukuran untuk mendapatkan berat bahansekitar 2,5 kg. Penggoreng vakum dipersiapkan dengan mengisi terlebih dahulu bak air hingga ketinggian $\pm 3 \mathrm{~cm}$ dari permukaan bak sirkulasi.
Kemudian minyak goreng dimasukkan kedalam tabung hingga dasar keranjang buah.Tombol pengendali suhu dipastikan masih pada posisi off saat menghubungkan regulator LPG dengan tabung. Suhu penggorengan penggoreng diatur pada $85-90^{\circ} \mathrm{C}$ lalu tekan tombol on pengendali suhu dan nyalakan kompor gas. Setelah tercapai suhu yang ditentukan (ditandai nyala kompor mengecil), bahan sekitar 2,5-4 kg dimasukkan ke dalam keranjang penggoreng maksimum kemudian ditutup. Pasang tutup tabung penggoreng dan kunci rapat-rapat, tutup kran pelepas vakum, nyalakan pompa dengan menekan tombol besar dalam posisi on pada boks pengontrol sambil membuka kran sirkulasi air di atas tabung jet, tunggu hingga air ke luar dari selang bagian atas kondensor. Setelah vakum meter menunjukkan angka 700-720 $\mathrm{mmHg}$, turunkan keranjang ke dalam minyak dengan memutar tuas pengaduk setengah putaran $\left(180^{\circ}\right)$. Goyanglah tuas setiap $10-15$ menit untuk meratakan pemanasan. Pada saat bahan dimasukkan ke dalam minyak, suhu akan turun, jarum meter vakum bergerak ke kanan, kaca pengintai menjadi berembun. Setelah matang, buih pada tabung penggorengan akan hilang (lihat dari kaca pengintai dengan menekan tombol lampu ke posisi on) angkat bahan keatas minyak dengan memutar tuas pengaduk $180^{\circ}$ dan kunci. Setelah \pm 2 menit, kemudian matikan pompa, kompor, dan kran sirkulasi air, kemudian buka kran pelepas vakum (di atas tutup) hingga vakum meter menunjuk angka 0 . Buka tutup tabung dan keranjang penggoreng, angkat keripik buah dan tiris kan pada mesin pengering/pengetus minyak dan keripik nangka siap untuk dianalisis.

Parameter yang digunakan untuk mengukur mutu keripik nangka adalah rendemen, warna, pengkerutan, dan kerapuhan. Warna keripik diukur dengan Chromameter CR-400, Minolta untuk mendapatkan nilai $L^{*}, a^{*}$, dan $b^{*}$. Kriteria warna keripik ditentukan berdasar nilai $\delta E^{*}$ [9]. Pengkerutan keripik nangka dihitung berdasar rasio kandungan air produk keripik nangka terhadap kandungan air buah nangka sebelum digoreng [9]. Kerapuhan keripik nangka ditentukan dengan Texture analyzer TA XT2i dengan probe bola model SS yang dioperasikan dengan kecepatan uji 0,5 mm per detik [7].

\section{Analisis Data}

Data yang didapat selanjutnya dianalisis dengan menggunakan uji ANOVA pada taraf 
kepercayaan 95\%. Uji lanjut BNT dilakukan untuk mengetahui perbedaan antar perlakuan.

\section{HASIL DAN BAHASAN}

Rendemen merupakan salah satu parameter produksi olahan pangan yang menggambarkan rasio produk yang didapat terhadap bahan bakunya. Rendemen keripik buah nangka yang diperoleh dari berbagai masa penanganan dari tingkat kematangan optimal disajikan pada Gambar 1.

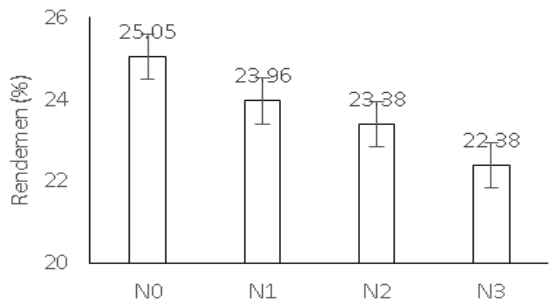

Gambar 1. Rendemen keripik nangka yang diperoleh dari berbagai masa penanganan dari tingkat kematangan optimal.

Hasil penelitian menunjukkan bahwa rendemen keripik nangka yang didapatkan hanya dari bahan baku nangka matang 1 hari $\left(\mathrm{N}_{1}\right)$ dari masak optimal yang tidak berbeda nyata dengan bahan baku nangka bermasak optimal 0 hari. Hal ini dimungkinkan tingkat respirasi pada buah nangka masak matang 1 hari dari masak optimal masih awal sehingga perubahan dan kehilangan massanya belum jauh berbeda dari buah masak optimalnya. Seiring dengan masa pengolahannya yang lama dari masak optimal maka tingkat respirasi buah akan semakin meningkat. Respirasi buah ini menghasilkan pembongkaran polisakarida menjadi gula terlarut air, dimana gula-larut ini pada saat proses pengolahan buah akan hilang dan mengakibatkan rendemen produk olahan menjadi rendah $[5,10,11]$.

Warna merupakan sifat fisikokimia produk pangan yang paling menjadi pertimbangan konsumen saat akan memilih suatu produk pangan walau warna sesungguhnya tidak menggambarkan kandungan gizi, cita rasa ataupun nilai kesehatan dari produk pangan tersebut. Warna keripik buah nangka yang diperoleh dari berbagai masa penanganan dari tingkat kematangan optimal disajikan pada Gambar 2.

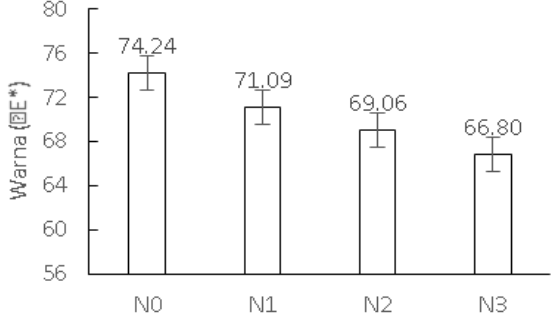

Gambar 2. Warna keripik nangka yang diperoleh dari berbagai masa penanganan dari tingkat kematangan optimal.

Gambar 2 menunjukkan warna keripik nangka yang dihasilkan hanya dari bahan baku nangka matang 1 hari $\left(\mathrm{N}_{1}\right)$ dari masak optimal yang tidak berbeda nyata dengan bahan baku nangka dari masak optimal 0 hari. Hal ini dimungkinkan karena kehilangan karotenoid buah bahan baku nangka matang 1 hari $\left(N_{1}\right)$ dari masak optimal yang paling tidak berbeda dengan kandungan karotenoid pada buah nangka dari masak optimal. Kemunduran kandungan karotenoid pada bahan baku keripik dari buah yang sudah 1 hari masak optimal ini tergolong masih rendah. Saat itu mungkin tingkat respirasi pada buah yang sudah 1 hari masak optimal masih berlangsung lamban. Penundaan pengolahan buah menjadi suatu produk akan meningkatkan respirasi pada buah yang berakibat pada semakin meningkatkan interaksi oksigen dengan karotenoid untuk mendegradasi pigmen tersebut. Salah satu faktor yang dapat merusak struktur kimia karotenoid adalah interaksi pigmen dengan oksigen $[3 ; 6 ; 12 ; 13 ; 14 ; 15]$.

Pengkerutan merupakan perubahan fisik yang selalu terjadi pada produk pengeringan. Pengkerutan keripik buah nangka yang diperoleh dari berbagai masa penanganan dari tingkat kematangan optimal disajikan pada Gambar 3 dan 4.

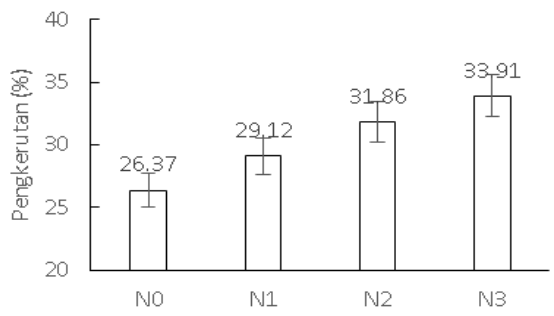

Gambar 3. Persentase pengkerutan keripik nangka yang diperoleh dari berbagai masa penanganan dari tingkat kematangan optimal. 

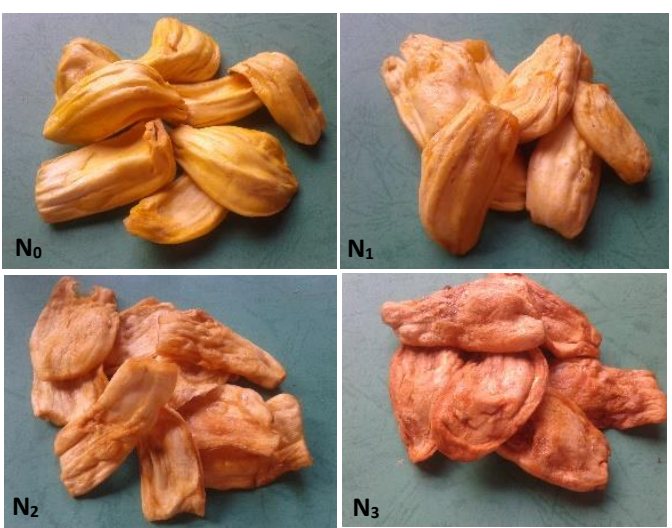

Gambar 4. Tingkat pengkerutan keripik nangka yang diperoleh dari berbagai masa penanganan dari tingkat kematangan optimal.

Gambar 3 dan 4 menunjukkan bahwa persentase dan tingkat pengkerutan keripik nangka yang dihasilkan dari hanya bahan baku nangka matang 1 hari $\left(N_{1}\right)$ dari masak optimal saja yang tidak berbeda nyata dengan bahan baku nangka masak optimal 0 hari. Respirasi menghasilkan peningkatan perpindahan osmose bahan, dimana banyak materi dari dalam sel akan keluar. Peningkatan ini akan meningkatkan kehilangan turgor buah sehingga buah kehilangan kesegaran. Semakin lama respirasi terjadi maka makin banyak kehilangan kesegarannya dan bila bahan tersebut dikeringkan akan memiliki produk yang struktur selnya sudah kehilangan isi atau mengkerut. [2].

Tekstur suatu produk kering dapat digunakan untuk menentukan mutu konsumsi produk kering tersebut. Kerapuhan adalah salah satu indicator tekstur produk yang menggambarkan seberapa besar gaya dari luar yang dapat mengakibatkan awal perubahan fisik produk. Kerapuhan keripik buah nangka yang diperoleh dari berbagai masa penanganan dari tingkat kematangan optimal disajikan pada Gambar 5.

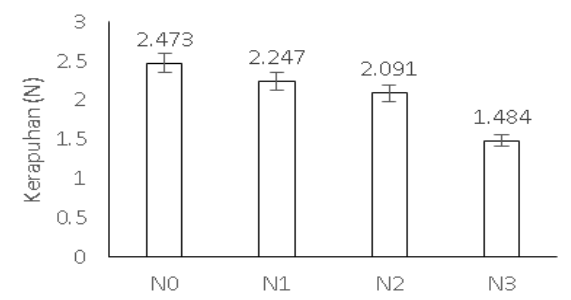

Gambar 5. Kerapuhan keripik nangka yang diperoleh dari berbagai masa penanganan dari tingkat kematangan optimal.
Gambar 5 menunjukkan kerapuhan keripik nangka yang dihasilkan dari hanya bahan baku nangka matang 1 hari $\left(\mathrm{N}_{1}\right)$ dari masak optimal yang tidak berbeda nyata dengan bahan baku nangka masak optimal 0 hari. Respirasi menghasilkan peningkatan pembentukan padatan terlarut bahan. Pembentukan materi ini menggambarkan adanya peningkatan hidrolisis terhadap polisakarida struktural dan nonstruktural buah. Semakin lama respirasi terjadi maka akan menghasilkan kehilangan struktural buah dan bila buah dalam kondisi telah mengalami respirasi cukup lama lalu dikeringkan, seperti digoreng akan memiliki produk yang rapuh $[2 ; 16]$.

\section{KESIMPULAN}

Keripik buah nangka yang diperoleh dari bahan baku buah nangka masak 1 hari dari masak optimal memiliki nilai rendemen, warna, pengkerutan, dan kerapuhan keripik nangka yang serupa dengan yang diperoleh dari buah nangka masak optimal.

\section{UCAPAN TERIMA KASIH}

Penelitian atau kajiwidya ini pembiayaannya dibebankan pada Dana APBN Tahun Anggaran 2012 DIPA Nomor: 7289/018-10.3.01/21/2012 tanggal 09 Desember 2011, Satker BAKORLUH Provinsi Nusa Tenggara Barat.

\section{DAFTAR PUSTAKA}

[1]. Hassan, K. 2010. Postharvest Handling of Fruits and Vegetables. Bangladesh Agricultural University. Mymensingh.

[2]. Toivonen, P.M.A. and D.A. Brummel. 2008. Biochemical bases of appearance and texture changes in fresh-cut fruit and vegetables. Postharvest Biology and Technology 48, 1-14

[3]. Khan, R., N. Zerega, S. Hossain, and M.I. Zuberi. 2010. Jackfruit (Artocarpus heterophyllus Lam.) Diversity in Bangladesh: Land Use and Artificial Selection. Economic Botany, 64(2): 124-136.

[4]. Azad, A. K., J. G. Jones and N. Haq. 2007. Assessing Morphological and Isozyme Variation of Jackfruit (Artocarpus heterophyllus Lam.) in Bangladesh. Agroforestry Systems, 71:109-125.

[5]. Selvaraj, Y., and D.K Pal,. 1989. Biochemical changes during the ripening of jackfruit (Artocarpus heterphyllus L.), Journal of Food Science \& Technology, 26 (6), 304-307. 
[6]. Rahman, M.A., N. Nahar, M.A. Jabbar and M. Mosihuzzaman. 1999. Variation of carbohydrate composition of two forms of fruit from jack tree (Artocarpus heterophyllus L.) with maturity and climatic conditions. Food Chemistry, 65: 91-97.

[7]. Maity, T., A.S. Bawa and P.S. Raju. 2014. Effect of vacuum frying on changes in quality attributes of jackfruit (Artocarpus heterphyllus) bulb slices. International Journal of Food Science. doi.org/10.1155/2014/752047

[8]. Giraldo-Zuñiga, A.D., A. Arévalo-Pinedo, R.M. Rodrigues, C.S.S. Lima and A.C. Feitosa. 2006. Kinetic Drying Experimental Data and Mathematical Model for Jackfruit (Artocarpus integrifolia) SLICES. Ciencia y Tecnologia Alimentaria, 5:2, 89-92

[9]. Sahin, S. and S.G. Sumnu. 2006. Physical Properties of Foods. Springer. New York.

[10]. Goswami, C., M.A. Hossain, H.A. Kader and R. Islam. 2011. Assessment of Physicochemical Properties of Jackfruits' (Artocarpus heterophyllus Lam) Pulps. Journal of Horticulture, Forestry and Biotechnology. 15(3): 26- 31

[11]. Ong, B.T., S.A.H. Nazimah, A. Osman, S.Y. Quek, Y.Y. Voon, D.M. Hashim, P.M. Chew and Y.W. Kong. 2006. Chemical and flavour changes in jackfruit (Artocarpus heterophyllus Lam.) cultivar J3 during ripening. Postharvest Biology and Technology, 40(3): 279-286

[12]. Ramel, F., A.S. Mialoundama and M. Havaux. 2013. Nonenzymic carotenoid oxidation and photooxidative stress signalling in plants. Journal of Experimental Botany, 64(3): 799-805

[13]. Boon, C.S., D.J. McClements, J. Weiss and E.A. Decker. 2010. Factors Influencing the Chemical Stability of Carotenoids in Foods. Critical Reviews in Food Science and Nutrition, 50(6): 515-532.

[14]. Bonnie, T. P. and Y. M. Choo., 1999. Oxidation and thermal degradation of carotenoids. Journal of Oil Palm Research, 2(1): 62-78.

[15]. Garavelli, M., F. Bernardi, M. Olivucci and M.A. Robb. 1998. DFT study of the reactions between singlet-oxygen and a carotenoid model. Journal of American Chemical Society, 120: 10210-10222.

[16]. Saxena. A., T. Maity, P.S. Raju and A.S. Bawa. 2015. Optimization of pretreatment and evaluation of quality of jackfruit
(Artocarpus heterophyllus) bulb crisps developed using combination drying. Food and Bioproducts Processing, 95: 106-117 